Abstracta Iranica Abstracta Iranica

Revue bibliographique pour le domaine irano-aryen

Volume 28 | 2007

Comptes rendus des publications de 2005

\title{
« The Arjan Tomb: Innovation and Acculturation in the Last days of Elam ». IA, 40, 2005, pp. 179-196.
}

\section{Rémy Boucharlat}

\section{(2) OpenEdition}

1 Journals

\section{Édition électronique}

URL : http://journals.openedition.org/abstractairanica/16492

DOI : 10.4000/abstractairanica.16492

ISSN : 1961-960X

Éditeur :

CNRS (UMR 7528 Mondes iraniens et indiens), Éditions de l'IFRI

\section{Édition imprimée}

Date de publication : 15 mai 2007

ISSN : 0240-8910

\section{Référence électronique}

Rémy Boucharlat, « «The Arjan Tomb: Innovation and Acculturation in the Last days of Elam ». IA, 40, 2005, pp. 179-196. », Abstracta Iranica [En ligne], Volume $28 \mid$ 2007, document 120, mis en ligne le 18 septembre 2007, consulté le 25 septembre 2020. URL : http://journals.openedition.org/ abstractairanica/16492 ; DOI : https://doi.org/10.4000/abstractairanica.16492

Ce document a été généré automatiquement le 25 septembre 2020.

Tous droits réservés 


\title{
«The Arjan Tomb: Innovation and Acculturation in the Last days of Elam ». IA, 40, 2005, pp. 179-196.
}

\author{
Rémy Boucharlat
}

1 Vingt ans après la découverte de la tombe d'Arjan, il était utile pour certains lecteurs de récapituler l'intérêt des principaux objets découverts comme témoins de l'émergence de l'art achéménide, dans cet "art hybride", non seulement élamite et proto-achéménide, mais également porteur d'indices assyriens, du Zagros central également, pense l'A., par la représentation de l'architecture défensive et d'origine inconnue pour la yourte (cf. récemment Abs. Ir. 27, c.r. $n^{\circ} 56$ et 108). Il est regrettable que cette tombe princière du début du $\mathrm{VI}^{\mathrm{e}} \mathrm{s}$. av. J.-C. dans le sud-ouest de l'Iran se trouve dans un quasi désert archéologique.

\section{INDEX}

Thèmes : 3.2.2. Pré-Achéménides et Achéménides

\section{AUTEURS}

RÉMY BOUCHARLAT

IFRI / CNRS - Téhéran / Lyon 